\title{
Study on Space Audit Assessment Criteria for Public Higher Education Institution in Malaysia: Space Capacity Assessment
}

\author{
Wan Samsul Zamani Wan Hamdan,a, Md. Yusof Hamid², Nor Amin Mohd Radzuan³ and Abdul Mutalib Aman Shah \\ ${ }^{1}$ PhD student, Faculty Architecture, Planning \& Surveying, Universiti Teknologi MARA, Shah Alam Campus, 40450, Selangor, Malaysia \\ 2,3 Faculty Architecture, Planning \& Surveying, Universiti Teknologi MARA, Seri Iskandar Campus, Seri \\ Iskandar,32610Perak,Malaysia \\ ${ }^{4}$ Amas FM Consultant Sdn Bhd (Malaysia)
}

\begin{abstract}
The aim of this study is to measure the capacity rate of learning space based on the as-built drawing provided by the institutions or if the as-built drawing is missing, the researcher have to prepare measured drawing as per actual on site. The learning space Capacity Index is developed by analyzing the space design in as-built drawing or measured drawing and the list of learning spaces available at the institution. The Capacity Index is classified according to the level of Usable Floor Area (UFA) and Occupancy Load (OL) according to learning space design capacity. The classification of Capacity Index is demonstrated through linguistic value and the color-coded key. From the said index, the institution can easily identify whether the existing learning space is currently best used or vice versa and standard space planning compliance in Malaysia Public Higher Education Institutions. The data will assist the management to clarify whether to maximize the use of existing space or to request for new learning space.
\end{abstract}

Keywords: Capacity index; learning space; space management; building survey; space capacity

\section{Introduction}

The government of Malaysia has introduced The Government Asset Management Policy (DPAK), in year 2009 as an effort to emphasis on asset management due to extensive amount of investments have been made to the development of assets [1]. In national budget, which announced for year 2016, the government had allocated RM 41 billion for education. As such the management of learning space is one of the most important aspects in the management of physical resources in Higher Education Institutions (HEI). The importance of space management is not just limited to improve capacity index but also related to the cost of maintenance operations. Any unattended space is a risk for the organisation and therefore its need urgent attention by the management. In order to improve capacity index in HEI, therefore learning space should be managed effectively and to avoid wasted spaces. If this is happened it will create uncomfortable learning environment, therefore will interfere with the student's focus that ultimately affect the quality of their learning. Environmental influences also a contributing factor to the failure or excellence of a student [2].

However, many institutions claim to have a lack of learning space [3]. In relation to this, Wamer and Leonard explained that most institutions of higher education is not optimizing the use of physical resources at particular times, such as lower consumption during the learning session, was not used in the evenings, nights, holidays and semester breaks [4]. The management of space is therefore an essential part of an asset management strategy for any institution [5]. Learning space should be effectively and efficiently managed as to optimize the building usage and at the same time can provide cost saving to the building operational cost. This study is important in identifying the 
learning space capacity in HEI. This paper begins with understanding on space management and space audit assessment in HEI. Then focused on space capacity through discussion in literature and analysis of once case study in HEI in Malaysia.

\section{Literature Review}

\subsection{Definition of Space Management}

Space management has been defined as "an art and science that maximize the value of existing space and minimize the need for new space"[6]. Space management is important for colleges and universities because it is the largest asset management services financial management system and also has a high investment value [6]. Space is also one of the most valuable resources on campus and high value that must be managed well to accommodate the needs of the high competition among institutions of higher learning [7]. Space management is not only important for financial reasons; the study also found that the space also affects individual responses psychological / physical in terms of their attitudes and behavior[8]. In particular, the physical environment affects how people interact [9], how students learn [10], how students decide where to register [11], and how knowledge is growing [7]. Space not only affects the individual, but also how the use of space can give a true picture direction and priorities of the institution[12], represents the values of the institution, and changing the culture of the institution[7].

Space management is a collaborative process skill in the art and science of maximizing the value, functionality and usability of the optimal space to create additional space requirements to a minimum. Space management is the most important aspect of public management of physical resources. Space management is considered important not only in terms of optimization, but also related to the cost of maintenance operations. But the cost implications associated with physical resources to the public is great [13]. Thus, the physical space should be managed efficiently to help the government in the optimal management of expenses and effective in order to enhance the implementation and achievement of the goals of the university. Space management must also be consistent with the Government Asset Management Policy and the demands of society, including those who are interested. In line with the introduction of the Government Asset Management Policy, Ministry of Higher Education of Malaysia (MOHE) took proactive steps to review and recommend the establishment of Best Practice Management of public space as public space management guidelines in Malaysia [13]. To determine the effectiveness and efficiency of space management in HEI is through space audit assessment at certain period and requirement.

\subsection{Definition of Space Audit in Higher Education Institutions}

Space audit is quite new in higher education institutions since for the past early years 2000. Not many researches had been done space audit studied since that until now. This is because many researchers are more focusing on facilities management fields in higher education institutions. However, since global economic environment drastically change in $20^{\text {th }}$ century with the rapid development of information technology in many institutions organization body, especially higher education. The implications from these scenarios influence higher education institutions changing the direction of the strategic management from expandable infrastructures asset to optimization facilities asset. At these moments, many higher education institutions make re-assessment existing facilities infrastructures to determine the efficiency of facilities usage especially space management. In determine the effectiveness and efficiency optimization space, a few higher education institutions produces space audit guideline for the process of space management performance. Previously only a few researcher or organization body defines about space audits. Michigan State University (2003) stated that, space audits are "a comprehensive review of currently assigned space for a College." It shows, space audit are all-inclusive detail action process in assess, revise, evaluate and verify the existing data or information about assigned space in campus. The analysis phase of the audit is a comparison of space utilization and distribution based upon departmental personnel rosters, space inventory data, and nationally used formulas and standards, which measure adequacy and effectiveness of space use in colleges and universities (Michigan State University, 2003). However, not at all space being revises, due to the Michigan State University space audit definition are more focusing on assigned space only (not included non-assigned space). Eventually, space audit process must be including as a whole features of space in determine entire space management performance of asset facilities in higher education institutions.

Facilities management consultant [14] also defined space audit as "a space audits are based on space utilisation survey data, and related information from college and university management systems". It can be understand that, space audit process must be depending on space utilisation report information data with including other information that related from overall university management systems. Space utilisation assessment are capability determine the effectiveness of space usage, but it did not cover-up overall performance of space management due to more focusing on space usage but other indicator component that also very relevant in determine space management performance such as space capacity, space physical condition, and equilibrium (balance) of space [15]-[17] Stellea [14] stated that, space audit definition also not specifically showing and explain on space audit areas categories that evaluate overall space management performance (assigned or non-assigned space). These various definitions of space audit in HEI statement shows that is "a process of 
comprehensive examination, assessment, reviewing and verification on capacity load, utilisation, physical condition and equilibrium space related data or information of existing assigned or non-assigned space inventory in academic or administrative aspects." The information obtained from a space audit is used to update the university's building and room inventory. An audit can include room-specific tours to confirm that space is used as designed, is occupied, and to assess the quality of the space and physical conditions of each room. The audit will note vacant space or other exceptions. Space audits provide information for the assessment of space allocations, prospective planning to accommodate changing situations and realignment of program priorities. The tools to analyse space audit assessment data is through space audit assessment criteria in HEI.

\subsection{Space Audit Assessment Criteria in Higher Education Institutions}

Most of the space audit assessment tool been establish and implemented by the HEI management are space utilisation rate. Space utilisation rate are multiply occupancy rate with frequency rate and divided by 100 to determine space utilisation rate and performance status. It also purposely for evaluate space need on existing space data. However, not many researchers focusing on other measurement factor that gave influence to space management performance which is space capacity and space condition. Therefore, new space audit evaluation measurement model been develop for HEI in Malaysia (Figure 1.1). However, for this paper, the study on covered only one assessment criteria, which is space capacity assessment

\begin{tabular}{|c|c|}
\hline \multirow{6}{*}{ 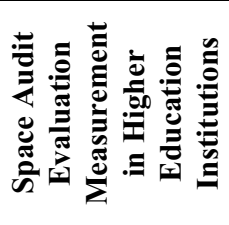 } & Measurement Criteria \\
\hline & Space Capacity \\
\hline & Space Occupancy \\
\hline & Space Frequency \\
\hline & Space Utilization \\
\hline & Space Condition \\
\hline
\end{tabular}

Sources: Author (2013)[18]

Figure 1.1: The Development Theoretical Framework for Space Audit Evaluation Measurement in Higher Education Institutions

\subsection{Space Capacity Assessment}

Space capacity assessment is a key element in this audit because it can measure the rate of use of a space and determine the maximum of capacity of space and density population of space usage. It also has positive effects such as [19]:

i. Identify areas of low use;

ii. Space management plan in accordance with the planning strategic organization;

iii. Forecast future space needs; iv. Facilitate spatial analysis;

v. Streamline the process of effective measures;

vi. Comparison of actual use than the use of planned, and

vii. Increasing awareness of the importance of space management efficient.

The main components of space capacity assessment are[19]:-
i. Space Capacity Maximum Measurement
ii. Space Capacity Index (Density) Measurement
iii. Space Capacity Index (Density) Score

\subsubsection{Space Capacity Maximum Measurement}

In measuring the space capacity, it is vital to understand the following terms used as follow:

a. Population Load (Occupancy Load)

b. Type of Floor Area (Usable Floor Area)

Population load that is also known as the occupant load means the size of area per people that appropriate and practical at designated space and can be used to determine number of filling in a space. The calculation is based on estimates of the population load space individual occupying that depends on the type of places and events different, for example the population load of classrooms not the same as the population load with workshop. Three steps to measure the capacity of a space building, is as follows:

a. Determine which categories of the population load will adopted. The load of this population may refer to standard planning standards by the government or the body the relevant professional agencies in the industry construction [20].

b. Determine the usable floor area (UFA) space. Calculation taking into accounts the whole area deduction or reduced by the space that cannot be occupied and used as walls, columns, stairs, utility room and so on. Here are the types of the calculated area based on the requirements:

i. Gross Floor Area ( GFA )

Total gross floor area encompasses an area of the floor is the main floor and the floor area ancillary.

ii. Main Floor Area ( MFA )

The total area enclosed spaces only measured in wall to wall including $\mathrm{M} \& \mathrm{E}$ ( Room motor elevator, water tank, AHU etc. ) but does not include space ansilari .

iii. Ancillary Floor Area (AFA)

The total area covered and open space, measured from wall to wall, including sidewalks, air space, open veranda, parking .

iv. Usable Floor Area (UFA)

Total floor area that can accommodate users taking into account the suitability of the related. 
Space Capacity Maximum Calculation:

Usable Floor Area

Occupancy Load

(Based on Standard and Cost Committee, 2008)

For examples, divide the total usable floor area (whether gross floor area or net) of the population load for example a room with 100 meters of gross floor area square with a load factor of 2.5 square meters. The space can accommodate a capacity of 40 people.

Example Calculation:

Space capacity based on usable floor area compared to the population load

$=\quad$ Usable floor area

Population Load space[20]

Samples: Capacity lecture hall:

M.p.s :

$$
\frac{100 \mathrm{~m} . \mathrm{s}}{2.5 \mathrm{~m} . \mathrm{p} . \mathrm{s}}=40 \text { students }
$$

$\sim 40$ student shows the maximum capacity of space for occupy at certain time in lecture hall.

\subsubsection{The Space Capacity Index (Density) Measurement}

To determine space capacity index for density populations in space management in HEI by applying space capacity index (density) measurement and score [19]. To measure space capacity index for density calculation by using formula and example calculation as follow:

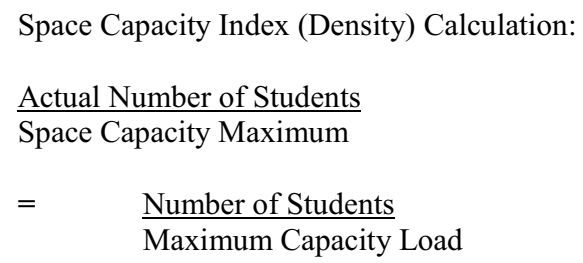

Example Calculation:

Samples: Capacity lecture hall:

$$
\begin{aligned}
& 31 \text { student } \times 100 \%=77.5 \% \\
& 40 \text { Students }
\end{aligned}
$$

$\sim 77.5$ per cent shows the space capacity index for density at lecture hall is high population with index 3 rate. It means total optimum use of space and efficiently with ensuring retain and remain at this category.

\subsubsection{The Score of Space Capacity Index (Density)}

Table 1.1 shows the definition of a space index score based on categories or percentage range is used as a benchmark or standard a uniform measure for all campuses involved. It also shows the level and range of index scores used as a benchmark or standard uniform in determine the status of the level of capacity utilization of space campus. Used more and more space, the more compact campus space and vice versa. According to MOHE space audit report (2011), level of space capacity index is divided into four (4): High Population Density, High Population, Medium Population and Low Population. Detail interpretation for level of space capacity index is further illustrated in Table 1.1.

\section{Methodology}

This study focuses on the formation of the model frameworks that related to space management of academic space in public higher education institutions in Malaysia. The new development frameworks are space audit assessment criteria in Tertiary Model. Implementation of the study is through literature review and case study of one sample of public university. Case study only focused on percentage space capacity performance for space audit assessment at 18 faculty buildings. The building comprises of main lecture theatre hall, classrooms and tutorial rooms for teaching and learning activities. At the end it showed the status of space capacity index (density) weather it was at high density space population or lower space population.

Three (3) data collection techniques were employed: Interviews, observations and document analyses on time table. Interviews are used to obtain further information on space usage. The owner and the occupant will be interviewed to confirm on the frequency, capacity and condition to validate the total numbers of student at the particular space. The practice of observation survey in space management is vital, whereby the person in-charge to be physically attached to the site to witness and validate the available schedule and actual on site.

The purpose of having time table is to ensure that every space is fully utilized. However superseded time table will contribute to misleading information. In some extent, the space is left vacant due to unavailability of new time table. All these three (3) technique data collection is to determine the actual number of student at various site of space.

Table 1.1: Space Capacity Category and Score Measurement 


\begin{tabular}{|c|c|c|c|c|c|}
\hline No. & Faculty & $\begin{array}{c}\text { Nos of } \\
\text { Students }\end{array}$ & \begin{tabular}{|c|} 
Maximum \\
room capacity \\
recommendatio \\
$\mathbf{n}$
\end{tabular} & $\begin{array}{l}* \text { Percentage } \\
\text { Performance } \\
\text { Capacity }(\%)\end{array}$ & Status \\
\hline 1 & $\begin{array}{l}\text { biology } \\
\text { science }\end{array}$ & 989 & 849 & $116 \%$ & $\begin{array}{c}\text { high } \\
\text { density }\end{array}$ \\
\hline 2 & Physics & 731 & 635 & $115 \%$ & $\begin{array}{c}\text { high } \\
\text { density }\end{array}$ \\
\hline 3 & \begin{tabular}{|l|} 
Chemical \\
Sciences
\end{tabular} & 620 & 542 & $114 \%$ & $\begin{array}{c}\text { high } \\
\text { density }\end{array}$ \\
\hline 4 & $\begin{array}{l}\text { Out Campus } \\
\text { Education }\end{array}$ & 294 & 260 & $113 \%$ & $\begin{array}{c}\text { high } \\
\text { density }\end{array}$ \\
\hline 5 & $\begin{array}{l}\text { Communicatio } \\
\text { ns }\end{array}$ & 516 & 460 & $112 \%$ & $\begin{array}{c}\text { high } \\
\text { density }\end{array}$ \\
\hline 6 & Arts & 543 & 492 & $110 \%$ & $\begin{array}{c}\text { high } \\
\text { density }\end{array}$ \\
\hline 7 & \begin{tabular}{|l|} 
Planning, \\
Housing \& \\
Buildings \\
\end{tabular} & 1064 & 988 & $108 \%$ & $\begin{array}{c}\text { high } \\
\text { density }\end{array}$ \\
\hline 8 & \begin{tabular}{|l|} 
Languages, \\
Literacies and \\
Translation \\
\end{tabular} & 582 & 551 & $106 \%$ & $\begin{array}{c}\text { high } \\
\text { density }\end{array}$ \\
\hline 9 & humanity & 1053 & 1005 & $105 \%$ & $\begin{array}{c}\text { high } \\
\text { density }\end{array}$ \\
\hline 10 & Social Sciences & 1224 & 1168 & $105 \%$ & $\begin{array}{c}\text { high } \\
\text { density }\end{array}$ \\
\hline 11 & \begin{tabular}{|l|}
$\begin{array}{l}\text { Computer } \\
\text { Sciences }\end{array}$ \\
\end{tabular} & 643 & 627 & $103 \%$ & \begin{tabular}{|c|} 
high \\
density
\end{tabular} \\
\hline 12 & Pharmacy & 894 & 875 & $102 \%$ & $\begin{array}{c}\text { high } \\
\text { density }\end{array}$ \\
\hline 13 & Education & 1814 & 1826 & $99 \%$ & high \\
\hline 14 & \begin{tabular}{|l}
$\begin{array}{l}\text { Graduate } \\
\text { Business }\end{array}$ \\
\end{tabular} & 444 & 447 & $99 \%$ & high \\
\hline 15 & $\begin{array}{l}\text { Industry } \\
\text { Technology }\end{array}$ & 696 & 708 & $98 \%$ & high \\
\hline 16 & $\begin{array}{l}\text { Mathematical } \\
\text { Sciences }\end{array}$ & 736 & 753 & $98 \%$ & high \\
\hline 17 & Management & 1755 & 1813 & $97 \%$ & high \\
\hline 18 & \begin{tabular}{|l|} 
Research \\
Center
\end{tabular} & 87 & 98 & $88 \%$ & high \\
\hline & Total Campus & 14685 & 14098 & $104.94 \%$ & $\begin{array}{c}\text { high } \\
\text { density }\end{array}$ \\
\hline
\end{tabular}

Note * This percentage is based on the total number of each faculty than the proposed maximum space capacity assuming students using this learning space without the use of other faculty space.

\begin{tabular}{|c|c|c|l|}
\hline $\begin{array}{c}\text { CATEGORY/ } \\
\text { SCORE }\end{array}$ & INDEX & $\begin{array}{c}\text { CAPACITY } \\
\text { (\%) }\end{array}$ & DESCRIPTION \\
\hline $\begin{array}{c}\text { High Density } \\
\text { Population }\end{array}$ & 4 & $>100 \%$ & $\begin{array}{l}\text { Overflow, } \\
\text { full,crowded, } \\
\text { jostling. Need to } \\
\text { proposed new space } \\
\text { requirement. }\end{array}$ \\
\hline $\begin{array}{c}\text { High } \\
\text { Population }\end{array}$ & 3 & $76 \%-100 \%$ & $\begin{array}{l}\text { Total optimal use } \\
\text { of space and } \\
\text { efficiently. Should } \\
\text { be maintained. }\end{array}$ \\
\hline $\begin{array}{c}\text { Optimum } \\
\text { Population }\end{array}$ & 2 & $\begin{array}{l}\text { Total partial use of } \\
\text { space optimal and } \\
\text { efficient. needs to } \\
\text { be improved until } \\
\text { optimal. }\end{array}$ \\
\hline $\begin{array}{c}\text { Low } \\
\text { Population }\end{array}$ & 1 & Under $59 \%$ & $\begin{array}{l}\text { Failed to reach the } \\
\text { total use of space } \\
\text { optimal and } \\
\text { efficient. need to } \\
\text { use } \\
\text { enhanced. }\end{array}$ \\
\hline
\end{tabular}

The selection case study were based on space audit assessment report of public higher education institutions (PHEI) in Malaysia (Mohe,2011). These reports were study

on three PHEI, which are cannot expose the name of PHEI due to restriction information. Therefore, for the purpose of these papers, only involve one (1) PHEI as University 1 with main purpose to determine the level of space capacity index (Density) performance for teaching and learning facilities at all faculty building at University 1 .

\section{Disscussion and Findings - Case Study}

The case study involved 3,589 learning space or academic rooms with equivalent of 112,692 square meters at University 1. To determine the Space Capacity Index of academic rooms at University 1 , the current student's number and maximum capacity load should be obtained first, as shown in figure 1.1. The Overall Space Capacity Index of academic room usage at University 1 in Semester 1 , Session 2011/2012 is at level 4. This indicates that the academic rooms capacities are in the high population density with an average percentage of $104 \%$ and it also mean overcrowded and need to develop additional academic building space for the future. Space management is considered important not only in terms of optimization but also related to the cost of maintenance operations.

Samples Data Analyses:

$\frac{989}{849}$ (Actual Students) $\quad=116 \%$

$\sim$ Status Space Capacity Index Score $=$ High Population Density (The space overload, crowded, full and jostling. Need to proposed new space requirement through find other existing space vacant and available or new building construction)

Figure 1.2- Overall Space Capacity Index Performance of Academic Space Overall Space Capacity Index Performance of Space Usage at University 1 at University 1 


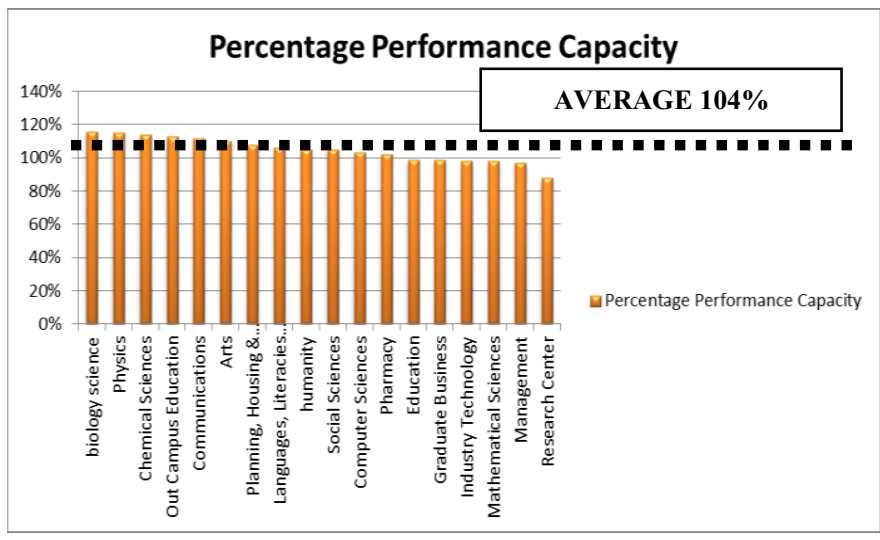

Figure 1.3- Overall Space Capacity Index Performance of Academic Space at University 1

\section{Conclusions}

All space in Higher Education Institutions, especially for public university must be managed efficiently and effectively by the organization of HEI. To obtain space capacity index, every HEI's to conduct space audit in stages or when it is deemed necessary by the top management. The ability to measure every learning space capacity in relation to the total number of student and standard of space planning will produce result of density for every space. The density will highlight the current space availability and also to be used for future space planning. The Space Capacity Index is one of the significant indicators to measure space usage besides frequency rate, condition rate, and occupancy rate. Based on the above case study, it is indicated that, most of the learning space has achieved high density with average capacity index of $104 \%$. The result of the capacity index to be read together with frequency, occupancy, utilization and condition rate before any decision made for space strategic planning either to maximize existing space or proposed new requirement space by new building construction.

\section{Acknowledgements}

The authors would like to express sincere thanks to the Ministry of Higher Education Malaysia, Twintech, UiTM (Sri Isnkandar), University of Malaya and all parties involves, in one way or another, for contributing to this study.

\section{References}

1. G. Malaysia., "Government Asset Management Policy," 2009.

2. M. N. B. Ismail, "Kajian Persek3taran Di Sebuah Kolej Universiti Terhadap Keselesaan Aktiviti Pengajaran
Dan Pembelajaran," Kolej Universiti Teknologi Tun Hussein Onn, 2002.

3. A. fauzi Wahab, "Pengurusan sumber fizikal ipt: pengurusan ruang," J. Teknol., vol. 43 (E), pp. 15-28, 2005.

4. and C. L. Warmer, D., The Income Generation Handbook. Buckingham : SRHE and Open Univerisity Press, 1992.

5. TEFMA, "TEFMA Strategic Aset Managment Workshop Report," Australia, 2009.

6. Hier TC \& Biddison GB, "Performance \& productivity: The space management mandate.," Facil. Manag., vol. 12, no. 2, pp. 16-23, 1996.

7. K. Holley and M. Harris, "Constructing the interdisciplinary ivory tower: The planning of interdisciplinary spaces on university campus," Plan. High. Educ., vol. 36, no. 3, pp. 34-43, 2008.

8. M. J. Graetz, K.A., \& Goliber, "The importance of physical space in creating supportive learning environments.," New Dir. Teach. Learn., 2002.

9. T. R. . Davis, "The Influence of the Physical Environment of Office," Acad. Manag. Rev., vol. 9, no. 2, pp. 271-283, 1984.

10. D. J. Bickford, N.V.N. Chism, The Importance of Physical SPace in Creating Supportive Learning Environments. San Francisco, US: Jossey-Bass, 2002.

11. A. W. June, "Facilities Play a Key Role in Students' Enrollment Decisions, Study Find," Chron. High. Educ., vol. 52, no. 40, p. A27, 2006.

12. I.Fink, "Research Space: Who Needs It, Who Gets It, Who Pays for It?," Plan. High. Educ., vol. 33, no. 1, pp. 7-17, 2004.

13. MOHE, "Space Audit Report on Optimization Usage in Public Higher Education in Malaysia," Putrajaya, Malaysia, 2012.

14. S. Limited and C. C. House, "The possible linking of institutions into effective educational and training agencies," vol. 44, no. 0, 2012.

15. Australasian Associate of Higher Education Facilities Officers (AAPPA), "Space Planning Guidelines Edition 2." AAPPA, Australia AAPPA, 2001.

16. S. Abdullah, L. S. Wee, F. Asran, and M. Nawi, "Application of Space Management in University towards Sustainable Usage," 2007.

17. S. M. Blanchette, "Space and Power in the Ivory Tower : Decision Making in Public Higher Education," University of Massachusetts, Boston, 2010.

18. W. S. Z. W. Hamdan, M. Y. Hamid, and N. A. M. 
Radzuan, "Space Management Issues in Higher Education Institutions in Malaysia," in $1 s t$ International Conference on Innovation and Technology for Sustainable Built Environment 2012 (ICITSBE 2012), 2012

19. M. of E. of M. MOE, Amalan Baik Pengurusan Ruang di Institusi Pengajian Tinggi Malaysia, Cetakan Pe. Kuala Lumpur, Malaysia: Penerbit Universiti Putra Malaysia, 2013.

20. E. P. U. of M. Standard and Cost Committee, "Garis Panduan dan Peraturan Bagi Perancangan Bangunan," 2008 . 